\title{
Erratum to: Tissue response to a new type of biomaterial implanted subcutaneously in rats
}

\author{
Marie Boennelycke • Lise Christensen • \\ Lene Feldskov Nielsen • Hanne Everland • Gunnar Lose
}

Published online: 10 February 2011

(C) The International Urogynecological Association 2011

\section{Erratum to: Int Urogynecol J}

$$
\text { DOI 10.1007/s00192-010-1257-3 }
$$

The number of animals used was 40 , not 30 as stated, so the first sentence of the second paragraph of "Material and Methods" (right column, p. 192) should have read as follows:

"The experimental animals were 40 adult Sprague-

Dawley rats weighing 295-435 g (Taconic, Denmark)."

The authors regret this error.

The online version of the original article can be found at http://dx.doi. org/10.1007/s00192-010-1257-3.

M. Boennelycke $(\triangle) \cdot G$. Lose

Department of Obstetrics and Gynecology,

Copenhagen University Hospital Herlev,

Herlev Ringvej 75,

2730 Herlev, Denmark

e-mail: boennelycke@dadlnet.dk

L. Christensen

Department of Pathology,

Copenhagen University Hospital Bispebjerg,

Copenhagen, Denmark

L. F. Nielsen $\cdot$ H. Everland

Coloplast A/S,

Humlebaek, Denmark 